\title{
SISTEM PEMANTAUAN LOKASI ANAK MENGGUNAKAN METODE GEOFENCING PADA PLATFORM ANDROID
}

\author{
Roly Segara ${ }^{1}$, Subari ${ }^{2}$ \\ 1Teknik Informatika, STIKI Malang \\ Email: roly@stiki.ac.id \\ 2Teknik Informatika, STIKI Malang \\ Email: subari@stiki.ac.id
}

\begin{abstract}
Kesibukan orang tua akhir-akhir ini telah menyita waktu mereka untuk berkumpul bersama keluarga. Tuntutan pekerjaan yang menyebabkan mereka harus berada di tempat kerja setiap hari menyebabkan perhatian dan pengawasan mereka terhadap keluarga terutama anak-anak menjadi berkurang. Belum lagi apabila para orang tua memiliki putra-putri yang sedang menempuh pendidikan di luar kota menyebabkan pengawasan terhadap anak-anaknya menjadi berkurang. Tidak jarang banyak ditemui kasus bahwa putra-putri mereka sering berbohong kepada orang tuanya ke mana mereka pergi. Hal ini tentu akan menimbulkan kekhawatiran terhadap para orang tua apalagi di masa seperti sekarang ini tempat-tempat hiburan bagi anak muda terdapat dimana-mana.

Sebagai salah satu solusi penulis membuat suatu sistem pemantauan lokasi anak untuk mengetahui dimana putra-putri mereka berada dan kemana saja putra-putri mereka bepergian. Sistem pemantauan lokasi anak merupakan sebuah sistem LBS (Location Based Services) dengan memanfaatkan GPS yang terdapat pada smartphone. Koordinat yang ditangkap oleh GPS dikirimkan ke server, kemudian server akan menampilkan lokasi keberadaan anak pada peta yang bisa diakses melalui website atau perangkat smartphone milik orang tua. Geofencing yang merupakan sebuah perimeter virtual pada wilayah geografis yang menggunakan layanan berbasis lokasi digunakan untuk pembatasan wilayah pengawasan anak. Apabila anak pergi melewati batas geofencing yang ditetapkan akan muncul notifikasin kepada orang tua berupa pesan atau alarm melalui perangkat smartphonenya.
\end{abstract}

Kata Kunci: GPS, geofencing

\section{PENDAHULUAN}

Salah satu solusi yang dilakukan oleh para orang tua untuk monitoring keberadaan anak adalah membekali putra-putri mereka dengan perangkat GPS (Global Positioning System) untuk mengetahui lokasi dimana putra-putri mereka berada dan kemana saja putraputri mereka bepergian. Namun harga yang cukup mahal dan biaya berlangganan dari provider yang menyediakan layanan personal tracker juga cukup tinggi menyebabkan kendala tersendiri bagi para orang tua terutama yang penghasilannya hanya cukup untuk memenuhi kebutuhan hidup sehari-hari.
Belum lagi perangkat GPS yang tampak dalam wujud fisik akan membebani putra-putri mereka yang merasa di awasi oleh orang tuanya sehingga tidak nyaman dalam bepergian. Dan hal yang terburuk adalah mereka akan meninggalkan perangkat GPS tersebut di suatu tempat, sedangkan mereka pergi ke tempat lain. Hal ini menyebabkan fungsi utama dari GPS sebagai alat pengawasan yang real time menjadi berkurang.

Solusi dalam penelitian ini adalah sebuah sistem LBS (Location Based Services) dengan memanfaatkan GPS yang terdapat pada smartphone. Koordinat yang ditangkap oleh GPS dikirimkan ke server, 
kemudian server akan menampilkan lokasi keberadaan anak pada peta yang bisa diakses melalui website atau perangkat smartphone milik orang tua. Geofencing yang merupakan sebuah perimeter virtual pada wilayah geografis yang menggunakan layanan berbasis lokasi digunakan untuk pembatasan wilayah pengawasan anak. Apabila anak pergi melewati batas geofencing yang ditetapkan akan muncul notifikasin kepada orang tua berupa pesan atau alarm melalui perangkat smartphonenya.

Penelitian ini bermaksud untuk mengimplementasikan sistem pemantauan terhadap lokasi anak menggunakan smartphone yang dapat mengirimkan data koordinat dari GPS smartphone ke web server dan memberikan informasi lokasi dari anak tersebut berdasarkan koordinat yang dikirim ke server tadi serta menyajikannya ke dalam sebuah peta digital yang dapat diakses oleh orang tua melalui website atau smartphone.

Tujuan utama dilakukan penelitian ini adalah untuk membuat sebuah sistem pemantauan lokasi anak berbasis Location Base Services yang akan mencatat track log dari posisi anak tersebut. Selain itu dengan menggunakan metode geofencing sistem akan memberitahukan kepada orang tua apabila anak telah melewati batas wilayah yang diijinkan oleh orang tua mereka.

Untuk menyelesaikan permasalahan diatas maka diberikan batasan-batasan sebagai berikut :

a. Perancangan sistem menggunakan platform Android versi 2.2 ke atas.

b. Aplikasi berjalan pada smartphone Android yang memiliki GPS dan memiliki kemampuan untuk koneksi ke internet.
C. Data yang digunakan adalah diambil dari data lokasi user yang terdiri dari longitude dan latitude.

d. Untuk pembatasan wilayah anak menggunakan Geo-Fencing dan akan ada notifikasin kepada orang tua apabila anak melewati batas yang telah ditentukan.

Dari penelitian yang dilakukan diharapkan dapat memberikan manfaat kepada orang tua, di antaranya:

a. Orang tua mengetahui keberadaan putra-putri mereka secara real time selama perangkat smartphone aktif dan terkoneksi ke internet.

b. Orang tua dapat mengetahui tempat dan waktu kemana putra-putri mereka pergi dengan melihat track log perjalanan yang tercatat.

c. Orang tua dapat mengetahui lokasilokasi mana saja yang sering dikunjungi oleh putra-putri mereka.

d. Orang tua dapat memberikan batasan ruang kemana putra-putri mereka pergi dengan adanya fitur geofencing.

\section{METODE PENELITIAN}

Metode penyelesaian masalah yang akan digunakan peneliti di dalam mengembangkan aplikasi ini adalah dengan membangun dua platform berbasis web sebagai pusat data informasi dan berbasis smartphone untuk data client, dengan membaca koordinat GPS dari perangkat bergerak yang akan dianalisa pada sisi server untuk pengolahan objek dengan metode geofencing.

Melacak dengan menggunakan GPS memerlukan sinyal aktif yang dikirim dari receiver GPS ke database atau stasiun pemantau melalui jaringan telepon seluler. Untuk melacak seseorang, barang, atau kendaraan dari lokasi yang bergerak maka orang atau organisasi yang ingin melakukan pelacakan tersebut harus 
memiliki akses terhadap bagian dari aplikasi yang didesain khusus untuk melacak.

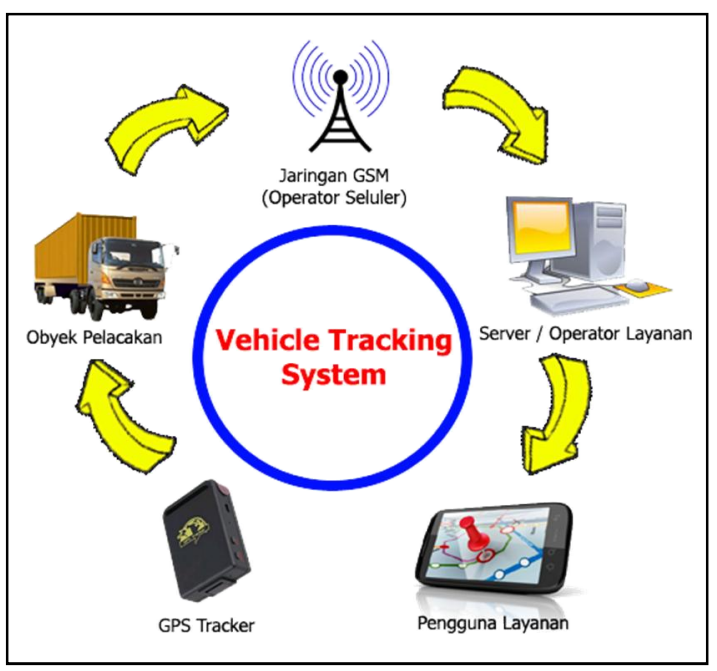

Gambar 1. Komponen utama sistem GPS pelacak

Receiver yang digunakan juga harus dilengkapi dengan modem seluler yang digunakan untuk mengirimkan data lokasi obyek yang sedang dilacak. Ponsel yang terbaru telah dilengkapi dengan hardware dan software GPS, sehingga untuk melacak seseorang yang membawa ponsel saat ini dapat dilakukan dengan mudah.

Selama melakukan pelacakan pribadi, sinyal yang diterima minimal harus diterima dari tiga satelit untuk menentukan lokasi yang tepat dari hardware tersebut, kemudian lokasinya dikirimkan secara langsung ke pengguna layanan melalui jaringan telepon seluler. Pelacakan GPS saat ini tidak mungkin dilakukan tanpa adanya hardware yang ditempatkan di lokasi yang dapat menerima sinyal setiap saat. Dalam beberapa kasus, pelacakan dapat dilakukan melalui telepon seluler yang di program untuk menerima pesan SMS yang memberitahu pelacak melalui telepon selulernya mengenai lokasi obyek yang dilacak pada waktu tertentu di siang dan malam hari. Pemantauan posisi dan pelacakan dapat dilakukan dengan menggunakan aplikasi komputer dan smartphone yang dilengkapi dengan map melalui jaringan internet.

Terdapat empat komponen pendukung utama dalam teknologi Location Based Service yang dapat dilihat pada gambar berikut ini.

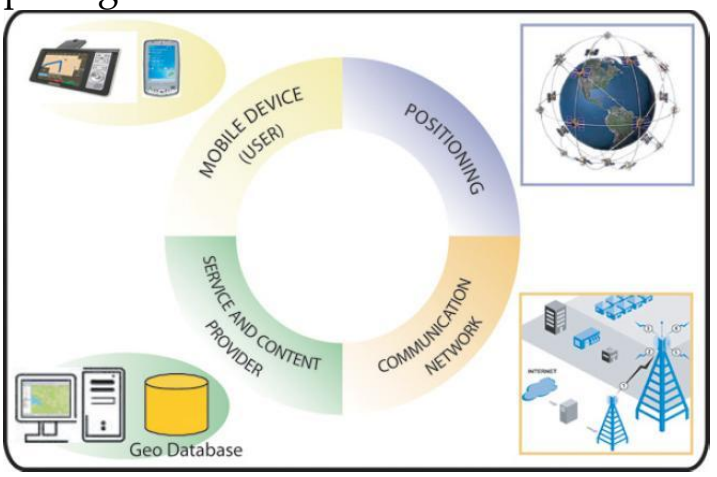

Gambar 2. Empat komponen utama pada Location Based Service

Geofence adalah sebuah pembatas dijital yang dapat diterapkan untuk memantau pergerakan obyek pada area tertentu, sehingga ketika GPS mendeteksi sebuah obyek yang dipantau melewati batas tersebut, maka sistem akan memberikan notifikasi kepada pemantau.

Sistem geofencing merupakan sistem yang dapat menganalisa dan melacak posisi obyek secara otomatis dan memberi laporan kapanpun dan dimanapun ketika obyek keluar atau masuk ke area-area geofence yang sebelumnya sudah ditentukan oleh pematau. Area geofence tersebut merupakan area berbentuk geometri virtual yang membatasi lokasi tertentu, seperti lokasi kantor, gudang, lokasi pelanggan, dan sebagainya. Sistem geofence ini dapat mengirim notifikasi kepada pemilik apabila kendaraan keluar atau masuk area geofence tertentu. 
Ilustrasi sebuah titik terhadap geofence dapat dilihat pada gambar di bawah ini.

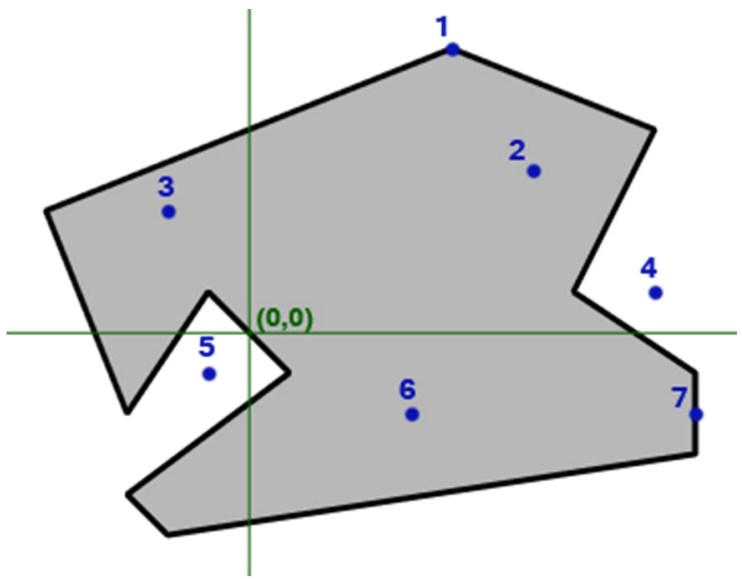

Gambar 3. Ilustrasi sebuah titik terhadap geofence

Dari gambar di atas, empat kemungkinan yang terjadi adalah:

a. sebuah titik berada di dalam polygon,

b. sebuah titik berada di luar polygon,

c. sebuah titik berada pada vertex (pertemuan dua garis yang membentuk sudut), dan

d. sebuah titik berada pada tepian garis.

Alur prosedur penelitian dapat digambarkan sebagai berikut:

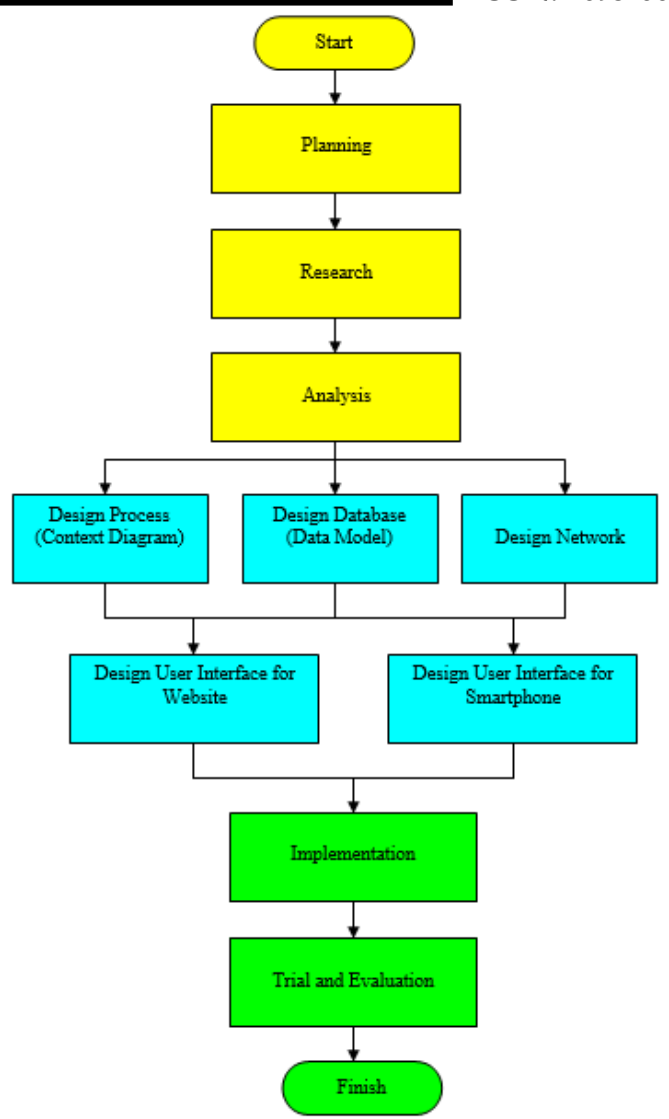

Gambar 4. Diagram alir prosedur pelaksanaan penelitian

Google Cloud Messaging (GCM) untuk Android adalah layanan yang digunakan untuk mengirim data dari server ke perangkat Android. Hal ini bias dijadikan pesan ringan untuk pemberitahuan pada aplikasi Android bahwa ada data baru yang akan diambil dari server (misalnya, film yang diunggah oleh seorang teman), atau bisa juga pesan text yang berukuran sampai dengan $4 \mathrm{~KB}$ data (sehingga aplikasi seperti instant messaging dapat menerima pesan secara langsung).

Layanan GCM ini menangani semua aspek antrian pesan dan pengiriman ke aplikasi Android yang berjalan pada perangkat client. GCM memungkinkan aplikasi android untuk mngirimkan pesan kepada server untuk membroadcast sebuah notifikasi kepada seluruh client yang ada. Agar dapat 
menggunakan fasilitas GCM ini kita harus melakukan registrasi terlebih dahulu menggunakan akun Gmail.

Secara garis besar cara kerja GCM dapat dilihat pada skema di bawah ini:

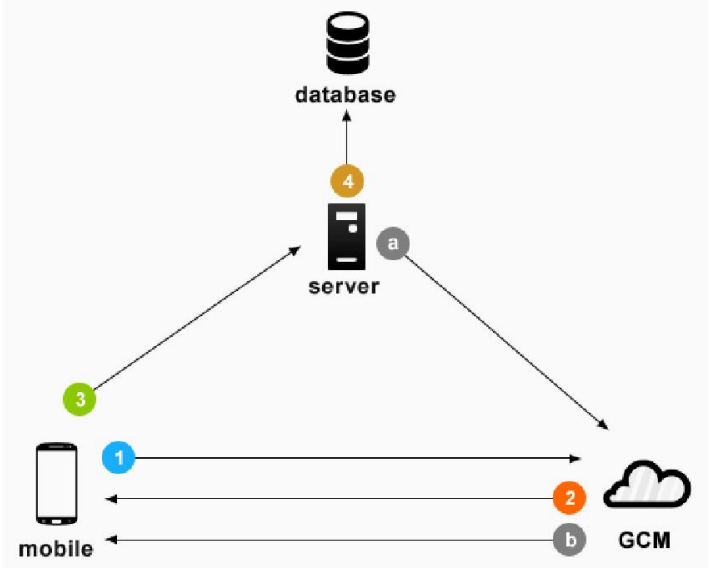

Gambar 5. Skema Google Cloud Messaging (GCM)

Keterangan Skema GCM:

1. Perangkat mengirim ID sender dan aplikasi ke GCM untuk registrasi,

2. Setalah berhasil, GCM memberikan ID registrasi ke perangkat,

3. Setelah menerima ID, perangkat mengirimkannya ke server kita,

4. Server menyimpan ID tersebut dalam database

a. Jika notifikasi dibutuhkan, server mengirim pesan ke GCM bersama dengan ID registrasi,

b. GCM mengirim pesan ke perangkat menggunakan ID registrasi.

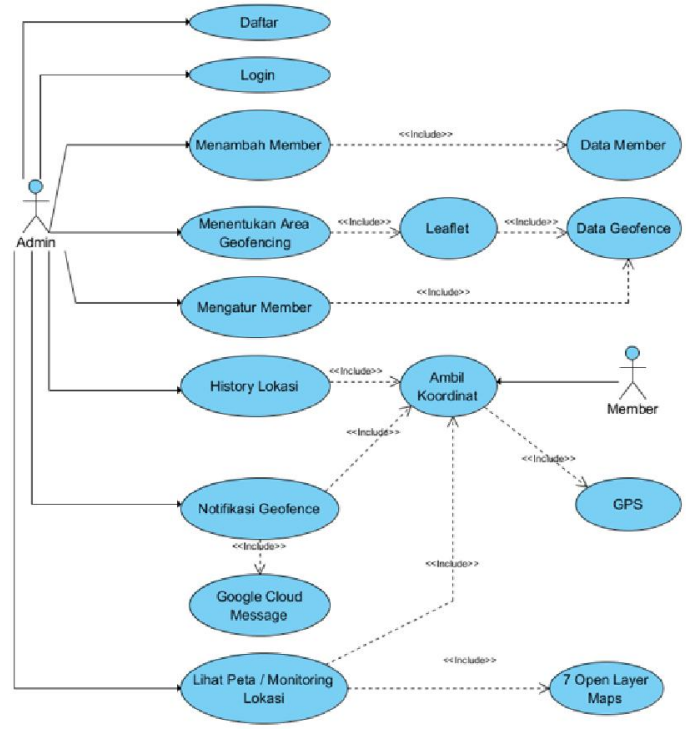

Gambar 6. Use case diagram sistem pemantauan lokasi anak

\section{HASIL DAN PEMBAHASAN}

Untuk membuat website monitoring anak penulis menggunakan framework CodeIgniter yang telah banyak digunakan oleh programmer PHP di Indonesia. Alasan menggunakan framework ini adalah karena telah didukung oleh konsep MVC (Model, View, Controller) dalam pengembangan website sehingga sangat mudah dalam mengatur file-file kode. Selain itu dukungan dokumentasi yang lengkap dari pengembang dan banyaknya tutorial di internet yang di publikasikan oleh pengguna CodeIgniter di Indonesia menjadi pertimbangan tersendiri bagi penulis.

Website monitoring lokasi anak ini diperuntukkan khusus bagi orang tua yang akan mengawasi anak-anaknya. Website ini digunakan sebagai alat administrator atau pengelolaan oleh orang tua terhadap hal-hal yang terkait dengan pengawasan anak, seperti pengaturan geofencing, pengaturan point of interest, pengaturan basecamp, monitoring lokasi, melihat jejak track $\log$ anak dan lain sebagainya. Pada halaman utama pada 
website monitoring lokasi anak ini terdapat dua tombol utama untuk login dan daftar akun baru bagi orang tua. Apabila orang tua telah mendaftar dan memiliki akun bisa langsung login. Apabila belum memiliki akun maka harus daftar akun terlebih dahulu.

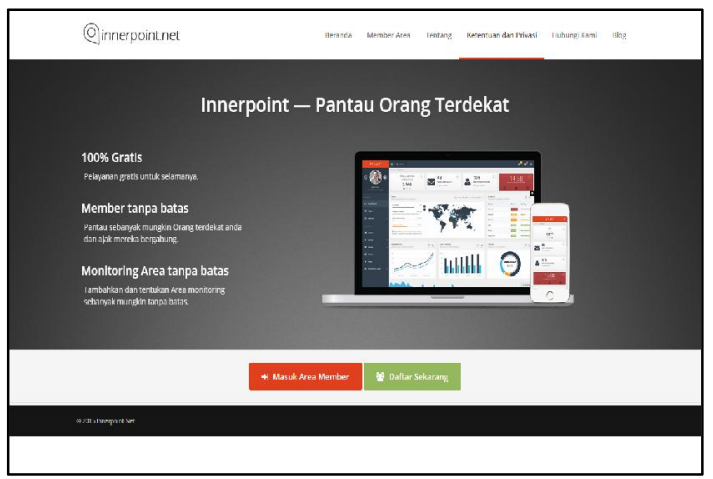

Gambar 7. Halaman utama website

monitoring anak www.innerpoint.net

Halaman dashboard member ini merupakan menu utama bagi orang tua. Dari halaman ini orang tua dapat mengakses fitur-fitur yang berkaitan dengan pengawasan anak seperti:
a. monitoring anak,
b. melihat jejak track log anak,
c. membuat geofence bagi anaknya,
d. membuat POI pada tempat-tempat tertentu pada peta,
e. membuat basecamp sebagai identifikasi tempat tinggal bagi anaknya,

f. mengatur profil, jadwal aktivitas harian, daerah terlarang dan

g. melihat statistik beberapa kondisi yang terjadi pada anak-anaknya.

Tampilan pada dashboard menu utama dapat dilihat pada gambar di bawah ini.

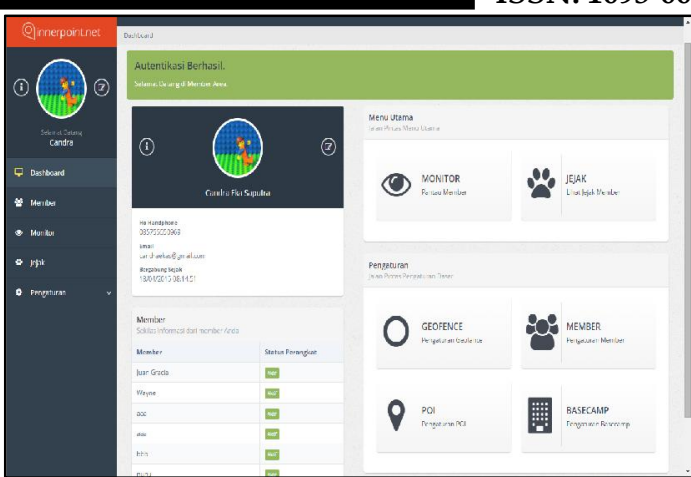

Gambar 8. Halaman dashboard/menu utama pada website monitoring anak

Halaman list member dapat diakses melalui menu "Member" pada dashboard/menu utama. Pada halaman ini terdapat daftar dari anak-anak yang telah ditambahkan oleh orangtuanya ke dalam sistem monitoring lokasi anak.

Berikut ini merupakan contoh orang tua yang memiliki delapan anak atau dalam sistem ini disebut sebagai member anak yang dapat dimonitoring oleh orang tua tersebut. Syarat agar anak dapat dimonitoring adalah perangkat Android anak harus sudah diregistrasi melalui aplikasi monitoring Android anak.

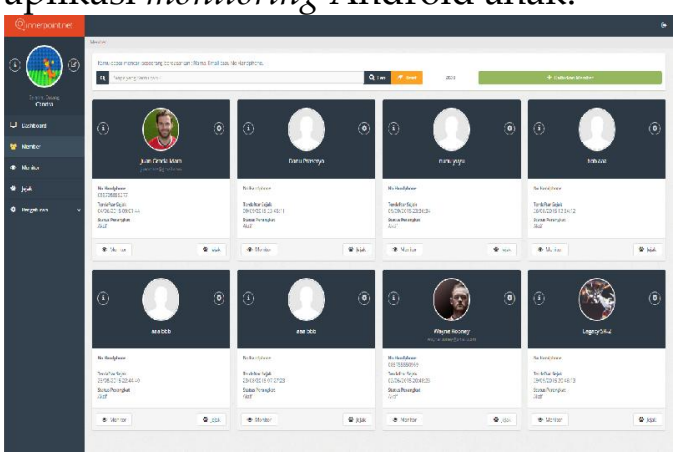

Gambar 9. Halaman list member

Halaman pengaturan member ini dapat diakses melalui menu "Pengaturan Dasar" pada masing-masing item member yang terdapat pada list member di atas. Setiap member anak pada sistem monitoring lokasi anak ini memiliki fiturfitur sendiri yang dapat meningkatkan fungsi dari pengawasan sehingga orang tua mendapatkan informasi yang lebih bermanfaat yang diberikan oleh sistem 
monitoring ini. Fitur-fitur yang dapat diatur oleh orang tua pada halaman ini antara lain:

a. Pemilihan Basecamp

Basecamp merupakan tempat tinggal dari seorang anak. Tidak harus rumah, bisa jadi tempat kos atau asrama yang ditinggali anak setiap hari.

b. Pengaturan Geofencing

Pada pengaturan geofencing ini terdapat tiga item yang bisa diaktifkan, yaitu:

- Aktifkan Geofence

- Peringatan Keluar Geofence

- Peringatan Masuk Geofence

c. Pemilihan Area Geofencing

Halaman monitoring dapat diakses melalui dashboard/menu utama dengan menekan tombol "Monitor" pada panel sebelah kiri. Melalui halaman ini orang tua dapat mengawasi posisi anaknya secara realtime. Halaman ini memiliki tiga bagian utama, yaitu:

a. panel vertikal sebelah kiri yang berisi daftar member anak,

b. peta monitoring pada panel sebelah kanan bagian atas dan

c. data-data atribut di panel sebelah kanan bagian bawah.

Data-data atribut tersebut berisi informasi seperti nama jalan, latitude, longitude, sisa baterai, kecepatan $(\mathrm{m} / \mathrm{s})$, ketinggian (mdpl), kekuatan sinyal dan lain-lain. Monitoring pada peta ini dilakukan secara realtime dengan refresh otomatis setiap sepuluh detik sekali. Jadi setiap sepuluh detik sekali posisi seorang anak pada peta ini akan diperbaharui.

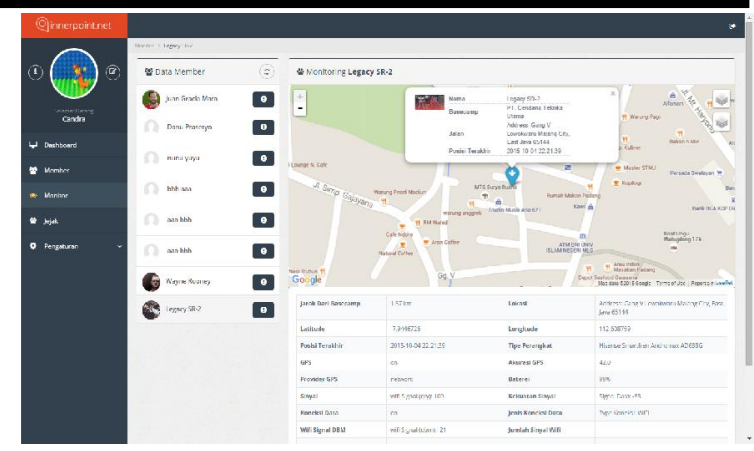

Gambar 10. Halaman monitoring posisi member anak

Halaman jejak member ini dapat diakses melalui dashboard/menu utama dengan menekan tombol "Jejak" pada panel sebelah kiri. Melalui halaman ini orang tua dapat melihat track log anaknya dalam dua tampilan yaitu: peta dan tabel. Pada tampilan peta tergambar track log dari seorang anak berupa garis-garis berwarna merah yang pada dasarnya merupakan kumpulan dari titik koordinat yang dikirim ke server dari perangkat Android anak secara berkala. Pada tampilan tabel berisi kumpulan informasi yang didapat dari data atribut selama proses monitoring. Halaman ini memiliki empat bagian utama, yaitu:

a. panel vertikal sebelah kiri yang berita daftar member anak,

b. peta jejak pada panel sebelah kanan bagian atas,

c. data-data atribut di panel sebelah kanan bagian bawah dan

d. ikon bulat yang berada di pojok kanan atas untuk mengganti ke tampilan tabel. 


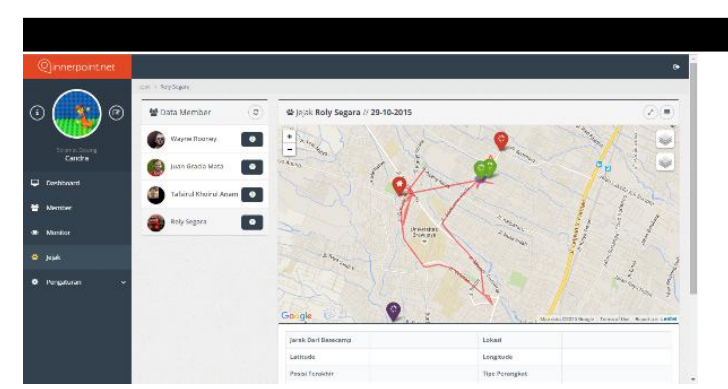

Gambar 11. Halaman jejak track log anak dalam bentuk peta

Gambar di bawah ini merupakan tampilan dari daftar geofence yang telah dibuat oleh orang tua. Melalui halaman ini orang tua juga dapat mengedit geofence yang telah dibuat.

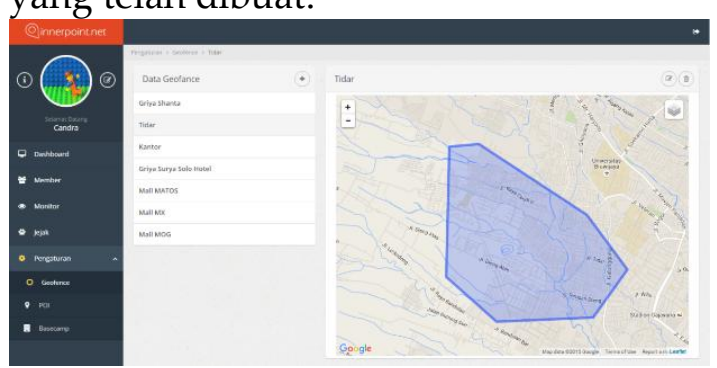

Gambar 12. Halaman daftar geofence

Gambar di bawah ini merupakan tampilan dari daftar POI yang telah dibuat oleh orang tua. Melalui halaman ini orang tua juga dapat mengedit POI yang telah dibuat.

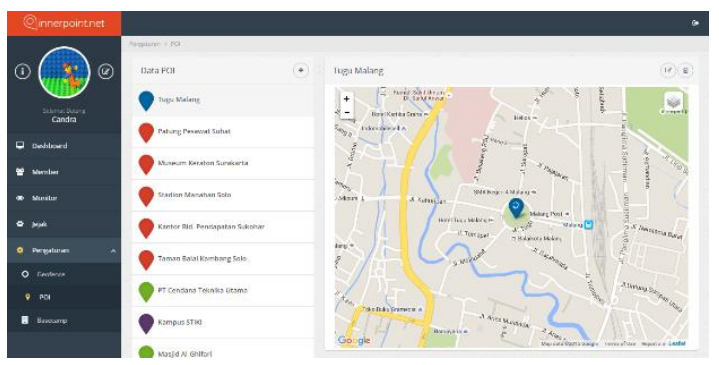

Gambar 13. Halaman daftar POI

Pada bagian aplikasi di Android, akan muncul form inputan data diri anak. Form ini akan muncul sekali ketika perangkat Android anak belum diregistrasi oleh orang tuanya. Field-field identitas yang harus diisikan oleh orang tuanya terdapat pada gambar form di bawah ini.

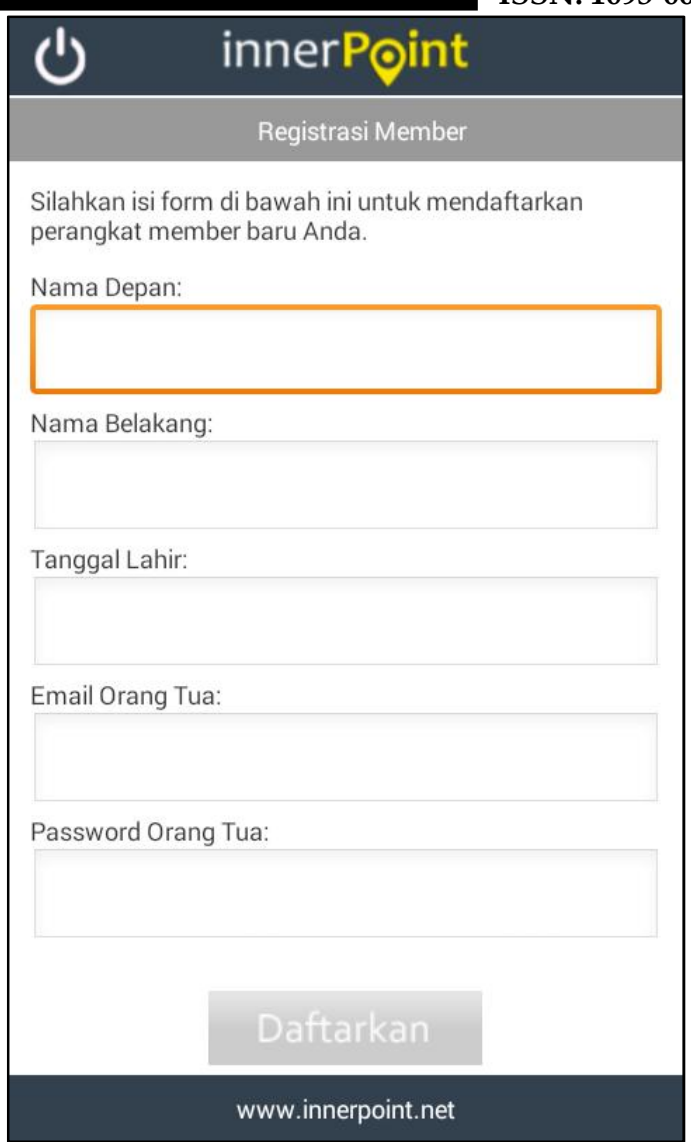

Gambar 14. Form registrasi perangkat Android Anak

Setelah orang tua menekan tombol "Daftarkan", data-data yang telah diisikan akan dikirim ke server, termasuk sebuah Android Device Id yang digunakan untuk mengenali perangkat Android anak. Android Device Id merupakan sebuah kode unik yang dimiliki oleh masingmasing perangkat Android yang terdiri dari 16 karakter alpha numeric.

Bila orang tua belum memiliki akun bisa melakukan registrasi terlebih dahulu melalui aplikasi ini dengan menekan tombol "Daftar" pada halaman login. Form yang harus diisi antara lain data diri orang tua dan otentifikasi akun yang terdiri dari email dan password. Email untuk registrasi harus menggunakan akun gmail agar perangkat orang tua dapat didaftarkan ke server GCM. Gambar berikut ini merupakan tampilan dari 
ISSN: 1693-6604

halaman registrasi orang tua beserta fieldfield yang harus diisi lengkap.

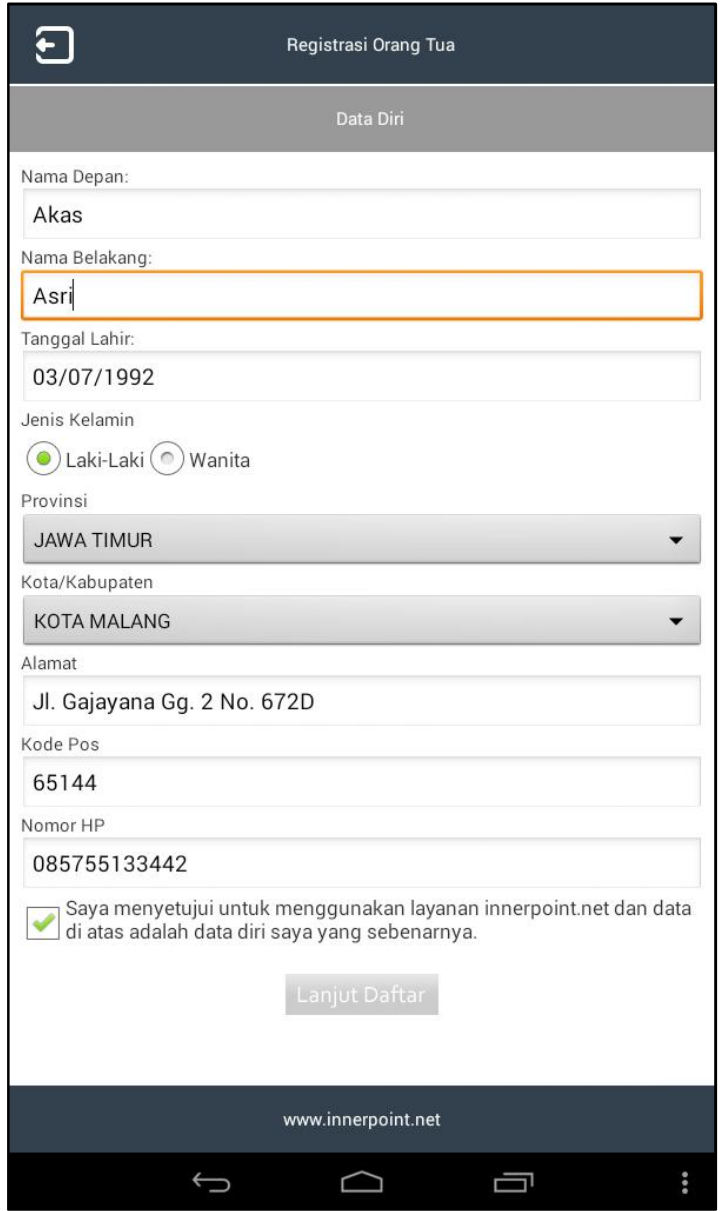

Gambar 15. Halaman registrasi untuk orang tua

Setelah orang tua mengisi form diatas lalu menekan tombol "Lanjut Daftar", maka sebuah form baru akan muncul. Form ini digunakan untuk otentifikasi akun atau untuk login nantinya, yang terdiri dari email dan password. Gambar berikut ini merupakan tampilan dari halaman otentifikasi akun beserta field-fieldnya yang harus diisi lengkap oleh orang tua.

Setelah melakukan login halaman menu utama akan tampil. Fungsi halaman ini sama seperti dashboard/menu utama pada website www.innerpoint.net. Untuk mengawasi anaknya, orang tua dapat menggunakan fitur-fitur monitoring yang dapat diakses melalui halaman ini seperti:
- monitoring,

- jejak track log,

- melihat notifikasi yang masuk,

- melihat statistik monitoring anak, dan

- melihat data detail dari anakanaknya.

Berikut ini adalah gambar tampilan dari menu utama aplikasi monitoring Android orang tua.

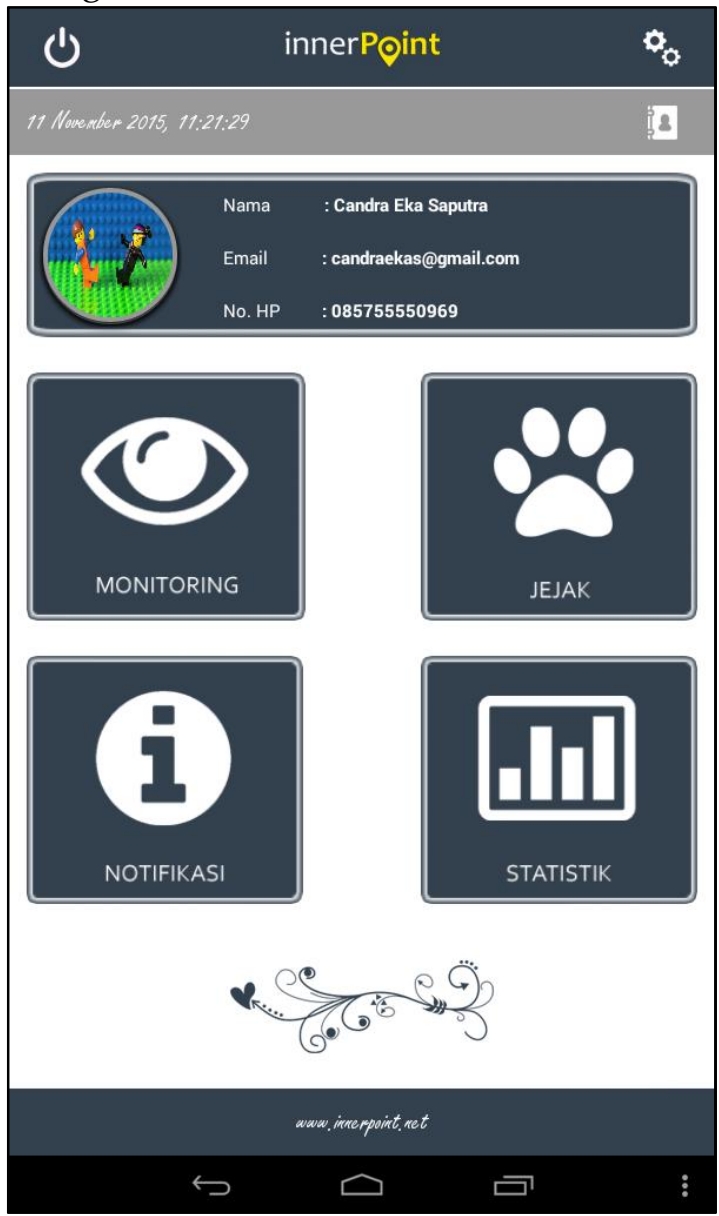

Gambar 16. Halaman menu utama pada aplikasi Android anak

Tampilan ini dibangun menggunakan layout $\mathrm{xml}$ yang terdiri dari empat widget imageView sebagai tombol utama.

Pada halaman menu utama ini orang tua dapat melihat daftar anaknya dan detail datanya dengan menekan sebuah icon kecil berbentuk buku kontak 
pada bagian atas sebelah kanan dari form ini. Berikut ini tampilan dari daftar member anak yang telah diregistrasikan oleh orang tuanya.

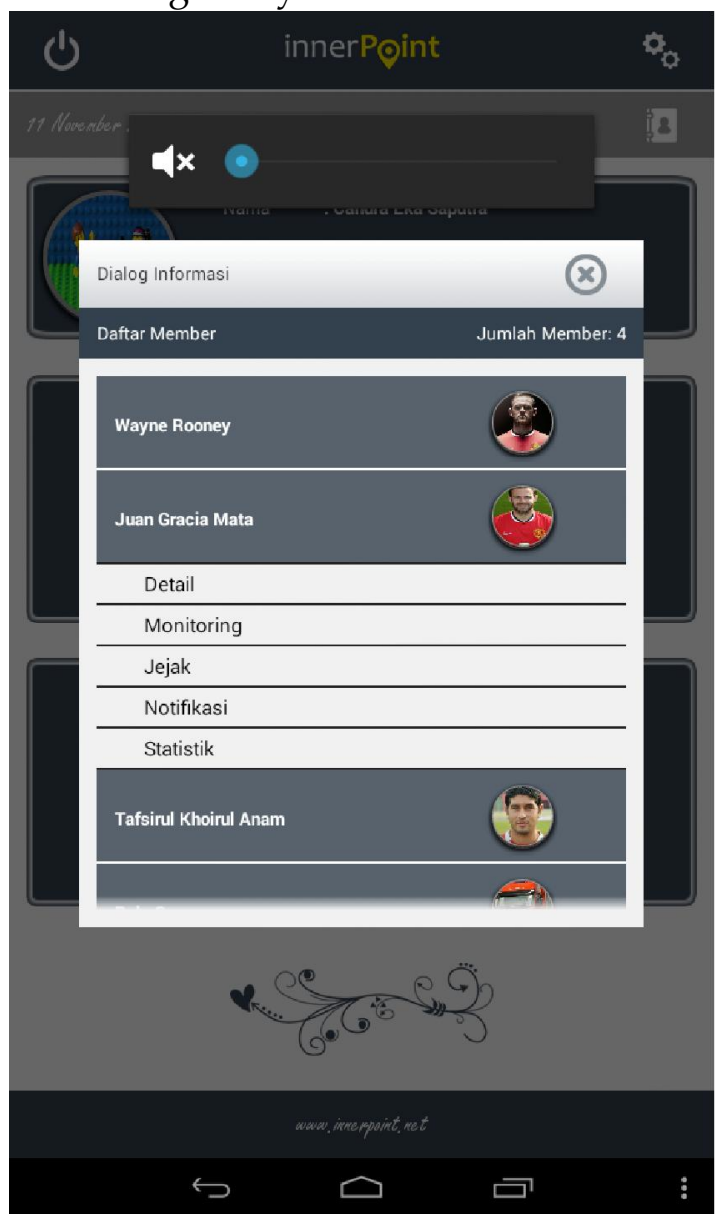

Gambar 17. Halaman daftar member anak

Dari dialog daftar anak di atas orang tua juga dapat mengakses beberapa halaman seperti monitoring, jejak, notifikasi, statistik dan detail data member anak. Pada bagian atas dari form dialog juga terdapat keterangan jumlah member anak yang telah diregistrasikan oleh orang tuanya. Berikut ini segmen program untuk menampilkan daftar member anak di atas.

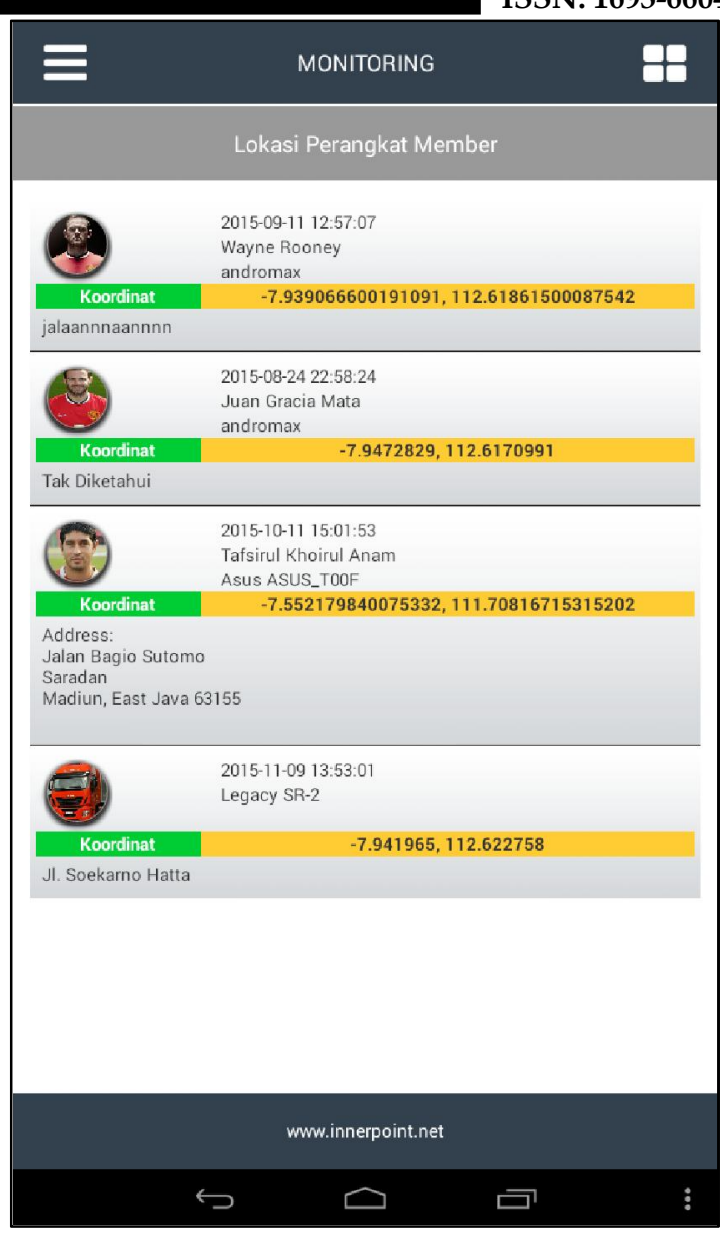

Gambar 18. Halaman daftar data monitoring anak

Pada daftar monitoring di atas apabila ditekan salah satu nama akan menampilkan peta yang menunjukkan posisi terakhir dari anak tersebut. Dan berikut ini adalah segmen program untuk menampilkan daftar monitoring anak.

Pada gambar selanjutnya ini menunjukkan posisi anak secara realtime pada peta. Apabila anak melakukan pergerakan maka marker yang mewakili anak pada peta juga ikut bergerak. Dalam aplikasi monitoring ini aplikasi anak setiap sepuluh milisecond sekali atau setiap terjadi perubahan posisi sejauh 30 meter akan mengirim posisi koordinat yang baru ke server. 
ISSN: 1693-6604

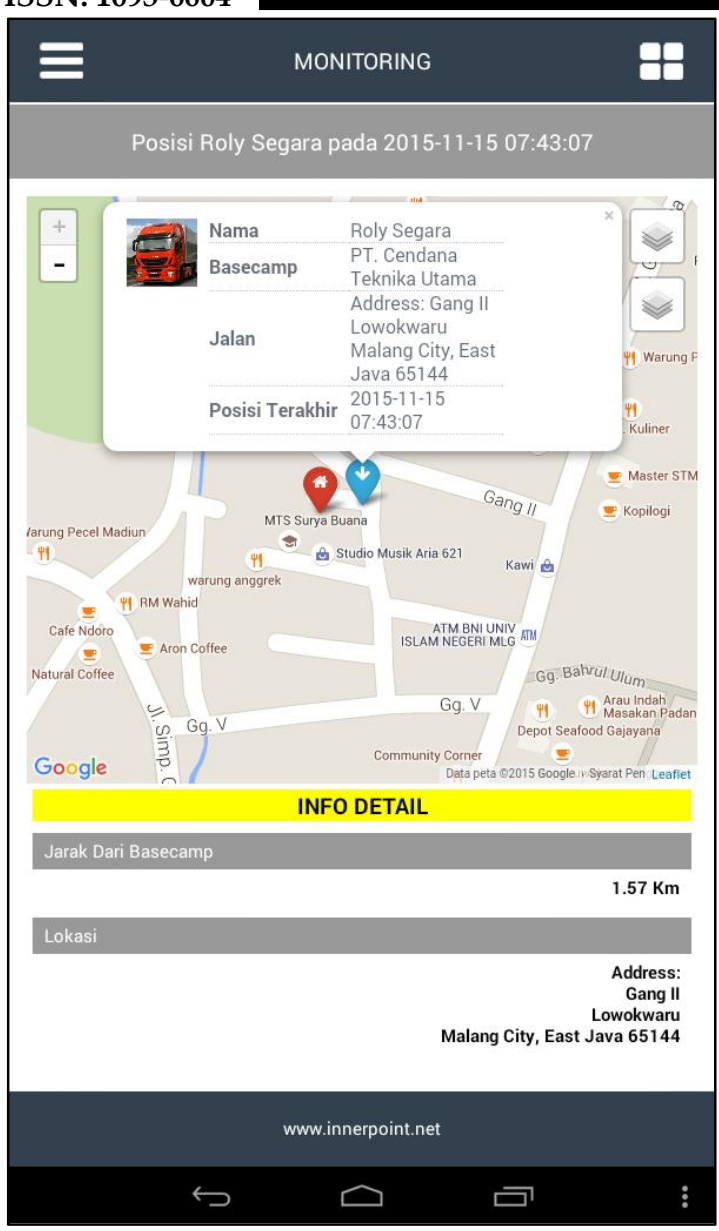

Gambar 19. Halaman posisi anak saat monitoring

Setelah pelacakan koordinat apabila ditemukan data jejak koordinat dalam periode tertentu, maka sistem akan menampilkan peta dengan garis berwarna merah yang merupakan jejak dari seorang anak seperti yang terlihat pada gambar di bawah ini.
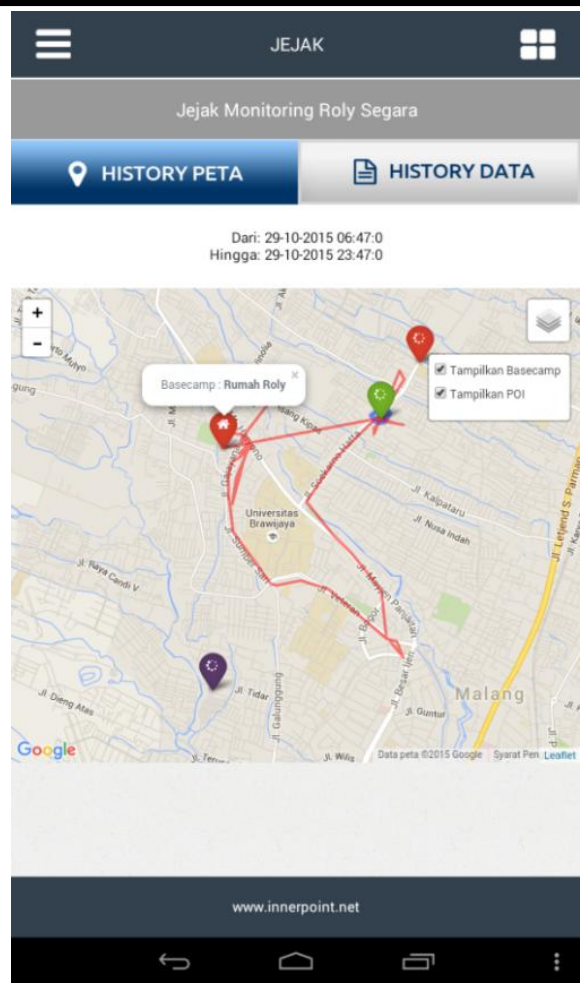

Gambar 20 Tampilan jejak track log anak dalam bentuk peta

Gambar di bawah ini merupakan tampilan dari data geofencing dalam bentuk dialog yang berisi informasi keluar/masuk geofence.

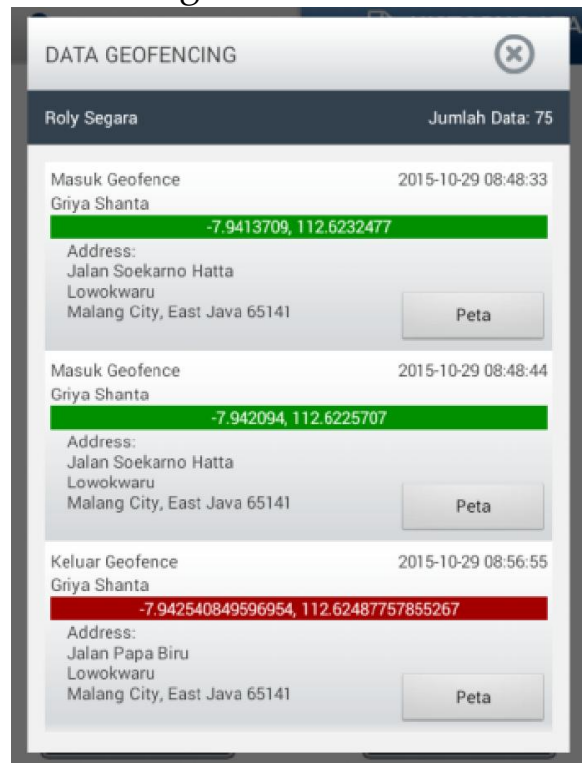

Gambar 21. Dialog menampilkan data geofencing

Gambar di bawah ini menunjukkan seorang anakyang keluar geofence 
terdeteksi oleh sistem pemantauan lokasi anak ini.

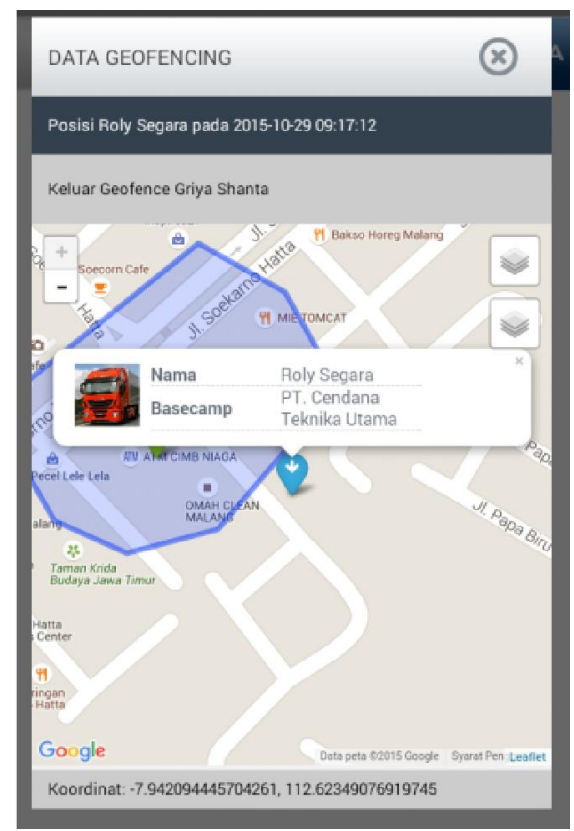

Gambar 22. Dialog menampilkan posisi anak saat keluar dari geofencing Gambar di bawah ini memperlihatkan seorang anak sedang mengunjungi tempat-tempat tertentu (POI) dan terdeteksi oleh sistem. Posisi dari seorang anak ditampilkan pada peta dalam mode satelit.

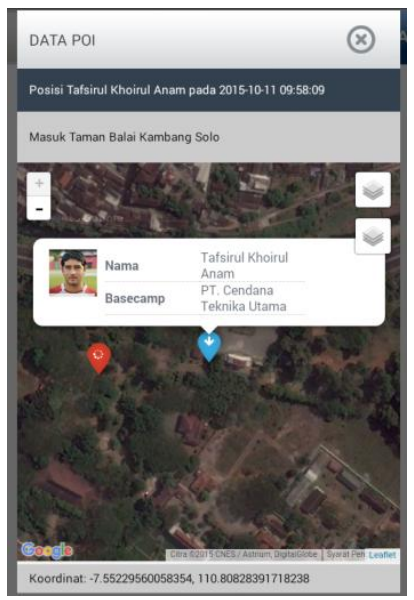

Gambar 23. Posisi anak saat memasuki

POI tertentu (mode peta satelit)

Gambar dibawah ini menampilkan data daerah terlarang yang menampilkan waktu keluar/masuk daerah tersebut.

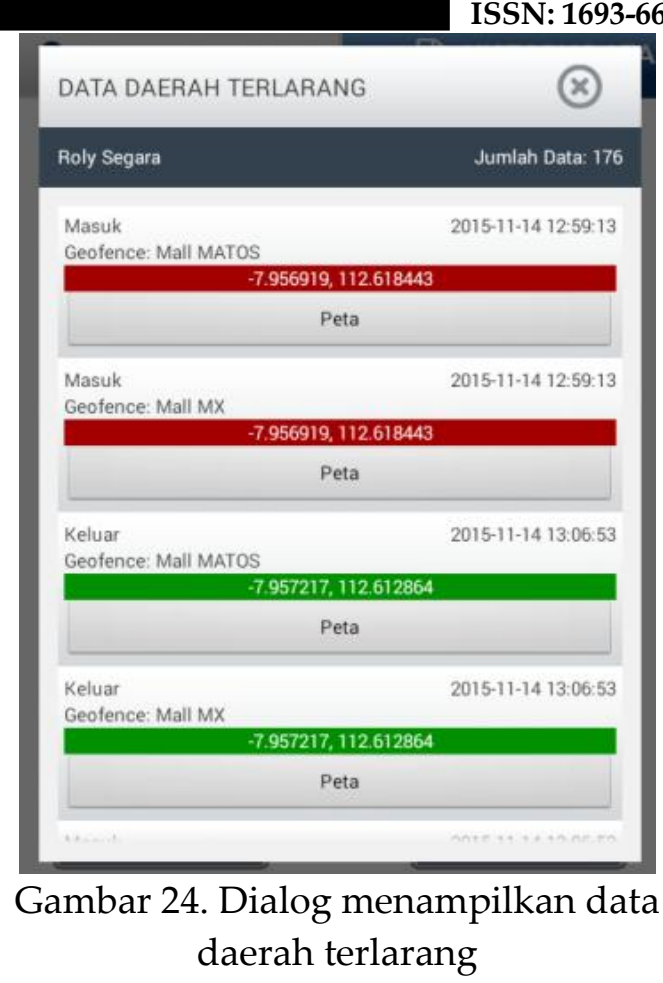

\section{KESIMPULAN}

Kesimpulan yang didapat adalah sebagai berikut :

a. Sistem pemantauan lokasi anak ini dapat mengambil koordinat GPS dari perangkat Android anak serta mengambil beberapa informasi dari perangkat tersebut dan mengirimkannya ke server.

b. Orang tua dapat memantau anaknya secara real time melalui website maupun perangkat Android yang telah diregistrasi terlebih dahulu.

c. Sistem pemantauan lokasi anak ini dapat mendeteksi posisi anak, keluar masuk area geofence, keluar masuk basecamp dan keluar masuk POI.

d. Sistem pemantauan lokasi anak ini dapat mengirim notifikasi ke perangkat Android orang tua apabila terjadi suatu kondisi tertentu.

e. Sistem pemantauan lokasi anak ini dapat menyimpan track log atau jejak dari seorang anak dan menyajikannya dalam bentuk rute pada peta dijital maupun dalam bentuk tabel yang 
ISSN: 1693-6604

berisi koordinat dan informasi lainnya.

\section{REFERENSI}

[1]. Admin. 2011. Mengenal SIG Dan Data Spasial. online, (http://osgeo.ft.ugm.ac.id/mengenalsig-dan-data-spasial/), diakses 14 Oktober 2013.

[7]. Dewi Yulianti, Fariani., Sarwosri, \& Nurul Khotimah, Wijayanti. (2013). Pengembangan Aplikasi e-Learning Jurusan Teknik Informatika ITS Berbasis Android pada Perangkat Komunikasi Bergerak. JURNAL TEKNIK POMITS (Vol. 2, No. 1, ISSN: 2337-3539 (2301-9271 Print)).

[2]. Admin. 2014. GIS (Geographic Information System). online, (http://integrasiautama.com/gisgeographic-information-system/), diakses 14 Juli 2015.

[3]. Admin. 2014. Membaca Koordinat GPS dengan Latitude dan Longitude. online, (http://obengplus.com/artikel/article s/161/1/Membaca-Koordinat-GPSdengan-Latitude-danLongitude.html\#.Vkh251Xtmkp), diakses 23 Juni 2014.

[4]. Agus Y.I, Putu., Sutanto, Teguh., \& M. Taufik, Vicky. (2012). Rancang Bangun Sistem Informasi Pelacakan dan Pemantauan Paket Kiriman Berbasis Web dengan Bantuan Mobile Android. Jurnal Sistem Informasi dan Komputerisasi Akuntansi (JSIKA) (Vol 1, No 2 ISSN: 2338-137X).

[5]. Ahmad, Anita. 2015. Pengertian Web Server Sebenarnya. online, (https://bukainfo.com/pengertianweb-server-sebenarnya/), diakses 15 November 2015.

[6]. Ardiansyah. 2011. Mengenal Location Based Service (LBS). online, (http://blog.uad.ac.id/ardi/2011/04/0 4/mengenal-location-based-servicelbs/), diakses 27 September 2013.

[8]. Habibi, Wildan., \& Mazharuddin S, Ary. (2011). Pembangunan Sistem Pelacakan Dan Penelusuran Device Mobile Berbasis Global Positioning Sistem (GPS) Pada Platform Mobile Google. Laporan Tugas Akhir S-1. Jurusan Teknik Informatika, Fakultas Teknologi Informasi, Institut Teknologi Sepuluh Nopember Surabaya.

[9]. Hanifah, Raidah., Rizal Isnanto, R., \& Christyono, Yuli. (2010). Simulasi Sistem Informasi Geografis (SIG) Pemantauan Posisi Kendaraan Via SMS Gateway. Jurnal Transmisi (Vol. 12, No. 2, ISSN 1411-0814). Hlm. 45-49.

[10]. Junus, M. (2012). Sistem Pelacakan Posisi Kendaraan Dengan Teknologi GPS \& GPRS Berbasis Web. Jurnal ELTEK (Vol 10 No 02, Oktober, ISSN 1693-4024).

[11]. M, Morenvino. (2008). Pembangunan Sistem Pelacakan dan Penelusuran Memanfaatkan Global Positioning System Pada Platform Mobile Google Android. Laporan Tugas Akhir S-1. Program Studi Teknik Informatika Sekolah Teknik Elektro Dan Informatika Institut Teknologi Bandung. 
[12]. Niessen, Michaël. 2009. PHP PointIn-Polygon Algorithm. online, (http://assemblysys.com/php-pointin-polygon-algorithm/), diakses 30 Mei 2015.

[13]. Pengenalan JSON. online, (http://www.json.org/json-id.html), diakses 12 Juni 2013.

[14]. Rifai, Ahmad.(2013). Sistem Informasi Pemantauan Posisi Kendaraan Dinas Unsri Menggunakan Teknologi GPS. Jurnal Sistem Informasi (JSI) (VOL. 5, NO. 2, Oktober, ISSN Print : 20851588, ISSN Online : 2355-4614).

[15]. Safaat H, Nazruddin. (2012). Android Pemrograman Aplikasi Mobile Smartphone Dan Tablet PC Berbasis Android. rev.ed. Bandung: Informatika.

[16]. Sisephaputra, Bonda., Supriyanto, Antok., \& Sutanto, Teguh. (2012). Sistem Pemantauan Keberadaan Jamaah Haji Menggunakan GPS Tracking Pada Smartphone Android (Studi Kasus : KBIH Al Ishlahiyyah Al Ghozaliyyah Tuban). Jurnal Sistem Informasi dan Komputerisasi Akuntansi (JSIKA) (Vol 1, No 1 ISSN: 2338-137X).

[17]. Soediatno, Supartono., Rahadian, Dirgantara., \& Kurniawan Gufron, Eko. (2012). Purwarupa Penampil Lokasi Manusia Menggunakan GPS dengan Koordinat Lintang-Bujur. Jurnal Informatika (Vol. 8, No. 1, Juni, ISSN: 0216-4280). Hlm. 23-47. 